\title{
Front Matter: Volume 6720
}

, "Front Matter: Volume 6720," Proc. SPIE 6720, Laser-Induced Damage in Optical Materials: 2007, 672001 (16 January 2008); doi: 10.1117/12.785402 Materials for High Power Lasers, 2007, Boulder, Colorado, United States 


\section{9th ANNUAL BOULDER DAMAGE SYMPOSIUM \\ Proceedings}

\section{LASER-INDUCED DAMAGE IN OPTICAL MATERIALS: 2007}

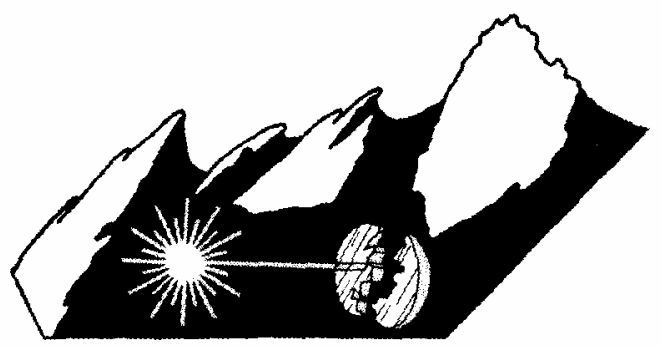

24-26 September 2007

Boulder, Colorado

Editors

Gregory J. Exarhos, Arthur H. Guenther, Keith L. Lewis

Detlev Ristau, M. J. Soileau, Christopher J. Stolz

\section{Organized by}

SPIE

Cosponsored by

Lawrence Livermore National Laboratory (USA)

\section{Cooperating Organizations}

Center for High Technology Materials, University of New Mexico (USA)

Pacific Northwest National Laboratory (USA)

Laser Zentrum Hannover e.V. (Germany)

National Institute of Standards and Technology (USA)

Electro-Magnetic Remote Sensing Defence Technology Centre (United Kingdom) College of Optics and Photonics, CREOL \& FPCE, University of Central Florida (USA)

\section{Published by}

SPIE 
The papers included in this volume were part of the technical conference cited on the cover and title page. Papers were selected and subject to review by the editors and conference program committee. Some conference presentations may not be available for publication. The papers published in these proceedings reflect the work and thoughts of the authors and are published herein as submitted. The publisher is not responsible for the validity of the information or for any outcomes resulting from reliance thereon.

Please use the following format to cite material from this book:

Author(s), "Title of Paper," in Laser-Induced Damage in Optical Materials: 2007, edited by Gregory J. Exarhos, Arthur H. Guenther, Keith L. Lewis, Detlev Ristau, M. J. Soileau, Christopher J. Stolz, Proceedings of SPIE Vol. 6720 (SPIE, Bellingham, WA, 2007) Article CID Number.

ISSN 0277-786X

ISBN 9780819468772

Published by

SPIE

P.O. Box 10, Bellingham, Washington 98227-0010 USA

Telephone +1 3606763290 (Pacific Time) · Fax +1 3606471445

SPIE.org

Copyright (C) 2008, Society of Photo-Optical Instrumentation Engineers

Copying of material in this book for internal or personal use, or for the internal or personal use of specific clients, beyond the fair use provisions granted by the U.S. Copyright Law is authorized by SPIE subject to payment of copying fees. The Transactional Reporting Service base fee for this volume is $\$ 18.00$ per article (or portion thereof), which should be paid directly to the Copyright Clearance Center (CCC), 222 Rosewood Drive, Danvers, MA 01923. Payment may also be made electronically through CCC Online at copyright.com. Other copying for republication, resale, advertising or promotion, or any form of systematic or multiple reproduction of any material in this book is prohibited except with permission in writing from the publisher. The CCC fee code is $0277-786 \mathrm{X} / 08 / \$ 18.00$.

Printed in the United States of America.

Publication of record for individual papers is online in the SPIE Digital Library.

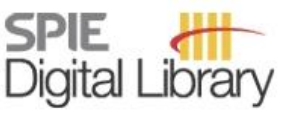

SPIEDigitalLibrary.org

Paper Numbering: Proceedings of SPIE follow an e-First publication model, with papers published first online and then in print and on CD-ROM. Papers are published as they are submitted and meet publication criteria. A unique, consistent, permanent citation identifier (CID) number is assigned to each article at the time of the first publication. Utilization of CIDs allows articles to be fully citable as soon they are published online, and connects the same identifier to all online, print, and electronic versions of the publication. SPIE uses a six-digit CID article numbering system in which:

- The first four digits correspond to the SPIE volume number.

- The last two digits indicate publication order within the volume using a Base 36 numbering system employing both numerals and letters. These two-number sets start with $00,01,02,03,04,05,06,07,08,09,0 \mathrm{~A}, 0 \mathrm{~B} \ldots 0 \mathrm{Z}$, followed by $10-$ $1 \mathrm{Z}, 20-2 \mathrm{Z}$, etc.

The CID number appears on each page of the manuscript. The complete citation is used on the first page, and an abbreviated version on subsequent pages. Numbers in the index correspond to the last two digits of the six-digit CID number. 


\title{
Contents
}

\author{
ix Foreword \\ G.J. Exarhos, A. H. Guenther, K. L. Lewis, D. Ristau, M. J. Soileau, C. J. Stolz \\ xi International Program Committee \\ xiii Symposium Welcome \\ C. J. Stolz \\ $\mathrm{xv} \quad$ Summary of Meeting \\ C. J. Stolz \\ xxv A Tribute to Dr. Arthur Guenther (1931-2007) \\ A. J. Glass
}

\section{FUNDAMENTAL MECHANISMS}

672002 Nanospallation induced by a femtosecond laser pulse (Invited Paper) [6720-01]

M. B. Agranat, Joint Institute for High Temperatures (Russia); S. I. Anisimov, Joint Institute for High Temperatures (Russia) and L.D. Landau Institute for Theoretical Physics (Russia); S. I. Ashitkov, Joint Institute for High Temperatures (Russia); V. V. Zhakhovskii, Joint Institute for High Temperatures (Russia) and Osaka Univ. (Japan); N. A. Inogamov, L.D. Landau Institute for Theoretical Physics (Russia); K. Nishihara, Osaka Univ. (Japan); Yu. V. Petrov, L.D. Landau Institute for Theoretical Physics (Russia)

672003 Progress in the understanding of fracture related laser damage of fused silica [6720-02] H. Bercegol, P. Grua, D. Hébert, J.-P. Morreeuw, CEA-CESTA (France)

672004 Photo-ionization of superlattices on dielectric surface by IR radiation [6720-03] V. E. Gruzdev, Univ. of Missouri-Columbia (USA)

672005 Does complex absorption behavior leading to conditioning and damage in KDP/DKDP reflect the electronic structure of initiators? [6720-04] M. D. Feit, P. P. DeMange, R. A. Negres, A. M. Rubenchik, S. G. Demos, Lawrence Livermore National Lab. (USA)

672006 A model of laser-induced damage of KDP based on the coupling of statistics and heat transfer [6720-05] G. Duchateau, A. Dyan, Commissariat à l'Energie Atomique (France)

672007 Thermal mechanism of laser-induced damages in KDP crystals [6720-14] A. Surmin, S. Lambert, F. Guillet, B. Minot, D. Damiani, CEA Le Ripault (France); F. Gervais, LEMA Lab, CNRS-CEA (France)

672008 Preliminary results on mitigation of KDP surface damage using the ball dimpling method [6720-11] F. Guillet, B. Bertussi, CEA/Le Ripault (France); L. Lamaignere, CEA/CESTA (France); X. Leborgne, B. Minot, CEA/Le Ripault (France)

672009 The effect of lattice temperature on surface damage in fused silica optics [6720-06] J. Bude, G. Guss, M. Matthews, M. L. Spaeth, Lawrence Livermore National Lab. (USA)

$67200 \mathrm{~A}$ Downstream intensification effects associated with $\mathbf{C O}_{2}$ laser mitigation of fused silica [6720-13] M. J. Matthews, I. L. Bass, G. M. Guss, C. C. Widmayer, F. L. Ravizza, Lawrence Livermore National Lab. (USA) 
$6720 \mathrm{OB}$ The exponential fitting of optical threshold and analyses of testing errors [6720-09]

D. Li, J. Shao, Y. Zhao, K. Yi, H. Qi, Shanghai Institute of Optics and Fine Mechanics (China)

$67200 \mathrm{C}$ Experimental and theoretical studies of subpicosecond laser damage in $\mathrm{Ti}_{\mathrm{x}} \mathrm{Si}_{1-\mathrm{x}} \mathbf{O}_{2}$ composite films [6720-10]

D. N. Nguyen, I. Cravetchi, L. A. Emmert, W. Rudolph, Univ. of New Mexico (USA); M. Jupe, M. Lappschies, K. Starke, D. Ristau, Laser Zentrum Hannover e.V. (Germany)

6720 0D Effect of laser pulse duration on damage to metal mirrors for laser IFE [6720-12]

J. E. Pulsifer, M. S. Tillack, Univ. of California, San Diego (USA); S. S. Harilal, Hyperion Scientific, Inc. (USA)

\section{SURFACES, MIRRORS, AND CONTAMINATION}

6720 0E James Webb Space Telescope: a large deployable cryogenic telescope in space (Invited Paper) [6720-22] P. A. Lightsey, Ball Aerospace and Technologies Corp. (USA)

$67200 \mathrm{~F} \quad$ Effects of wavelengths combination on initiation and growth of laser-induced surface damage in $\mathrm{SiO}_{2}$ [6720-23]

L. Lamaignere, S. Reyne, M. Loiseau, J.-C. Poncetta, H. Bercegol, CEA-Ctr. d'Etudes Scientifiques et Techniques d'Aquitaine (France)

6720 0G Damage thresholds and morphology of the front- and back-irradiated $\mathrm{SiO}_{2}$ thin films containing gold nanoparticles as artificial absorbing defects [6720-19]

S. Papernov, A. W. Schmid, J. B. Oliver, A. L. Rigatti, Univ. of Rochester (USA)

$6720 \mathrm{0H} \quad$ Growth of laser damage in fused silica: diameter to depth ratio [6720-25]

M. A. Norton, J. J. Adams, C. W. Carr, E. E. Donohue, M. D. Feit, R. P. Hackel, W. G. Hollingsworth, J. A. Jarboe, M. J. Matthews, A. M. Rubenchik, M. L. Spaeth, Lawrence Livermore National Lab. (USA)

6720 OI Extended lifetime of fluoride optics [6720-24]

J. Wang, C. R. Clar, H. Schreiber, Corning Tropel Corp. (USA)

6720 0J Analysis of output surface damage resulting from single $351 \mathrm{~nm}, 3 \mathrm{~ns}$ pulses on sub-nanosecond laser conditioned $\mathrm{KD}_{2} \mathrm{PO}_{4}$ crystals [6720-57]

J. A. Jarboe, J. J. Adams, R. P. Hackel, Lawrence Livermore National Lab. (USA)

6720 0K Damage characteristics at optical fiber connector for high power light transmission [6720-28]

S. Matsuda, T. Shibuya, M. Wakaki, Tokai Univ. (Japan)

6720 0L High laser damage threshold surface relief micro-structures for anti-reflection applications (Best Oral Presentation) [6720-68]

D. S. Hobbs, B. D. MacLeod, TelAztec LLC (USA)

6720 0M Revisiting mechanisms of molecular contamination induced laser optic damage [6720-15] J. S. Canham, ATK Space Inc. (USA)

$67200 \mathrm{~N}$ Optimizing a cleaning process for multilayer dielectric (MLD) diffraction gratings [6720-17] B. Ashe, C. Giacofei, G. Myhre, A. W. Schmid, Univ. of Rochester (USA)

$67200 \mathrm{O} \quad$ Fluorescence monitoring of organic deposits [6720-26]

H. Schröder, German Aerospace Center (DLR) (Germany); S. Becker, Y. Lien, ESA-ESTEC (Netherlands); W. Riede, German Aerospace Center (DLR) (Germany); D. Wernham, ESA-ESTEC (Netherlands)

$67200 \mathrm{P}$ Operational experience of contamination and damage of the larger aperture optics in the HELEN laser facility vacuum system at 1053 and $\mathbf{5 2 7}$ nanometres [6720-27]

J. Andrew, M. Girling, N. Honiatt, D. Scott, P. Wallace, AWE plc (United Kingdom) 
6720 0Q Studies on thin films as short pulse laser debris shields [6720-18]

J. Schwarz, P. Rambo, M. Geissel, Sandia National Labs. (USA); D. Headley, M. Ramsey, American Staff

Augmentation Providers (USA); B. Atherton, Sandia National Labs. (USA)

\section{THIN FILMS}

6720 OR A laser preconditioning process for improving the laser damage threshold, and the search for subtle laser damage from long-duration laser exposure for IBS thin films (Invited Paper) [6720-29]

D. C. Ness, A. D. Streater, Research Electro-Optics, Inc. (USA)

6720 OS Laser damage of silica and hafnia thin films made with different deposition technologies [6720-30] L. Gallais, J. Capoulade, J.-Y. Natoli, M. Commandré, M. Cathelinaud, C. Koc, M. Lequime, Institut Fresnel, CNRS (France)

6720 0T Performance enhancement of ion beam sputtered oxide coatings for $193 \mathrm{~nm}$ [6720-31]

H. Blaschke, M. Lappschies, D. Ristau, Laser Zentrum Hannover e.V. (Germany)

$67200 \mathrm{U} \quad$ Mixed oxide coatings for advanced fs-laser applications [6720-32]

M. Jupé, M. Lappschies, L. Jensen, K. Starke, D. Ristau, Laser Zentrum Hannover e.V. (Germany);

A. Melninkaitis, V. Sirutkaitis, Vilnius Univ. (Lithuania); I. Cravetchi, W. Rudolph, Univ. of New Mexico (USA)

$67200 \mathrm{~V}$ Effect of electric-field distribution on the laser damage probability curves of multilayer coatings [6720-33]

H. Krol, CILAS Marseille (France); C. Amra, Institut Fresnel, CNRS (France); C. Grèzes-Besset, CILAS

Marseille (France); M. Commandré, Institut Fresnel, CNRS (France)

$67200 \mathrm{~W} \quad$ Laser-induced damage of multilayer high-reflectance coatings for $248 \mathrm{~nm}$ [6720-34]

H. Qi, K. Yi, H. Yu, Y. Cui, D. Li, Shanghai Institute of Optics and Fine Mechanics (China); Z. Gao, China

Institute of Atomic Energy (China); J. Shao, Z. Fan, Shanghai Institute of Optics and Fine Mechanics (China)

$67200 \mathrm{X}$ Influence of process conditions on the optical properties of $\mathrm{HfO}_{2} / \mathrm{SiO}_{2}$ coatings for high-power laser coatings [6720-35]

B. Langdon, D. Patel, E. Krous, J. J. Rocca, C. S. Menoni, Colorado State State Univ. (USA); F. Tomasel, Advanced Energy, Inc. (USA) and Colorado State State Univ. (USA); S. Kholi, P. R. McCurdy, Colorado State Univ. (USA); P. Langston, A. Ogloza, Naval Air Warfare Ctr. (USA)

$67200 \mathrm{Y}$ Influence of electric field distribution on laser induced damage threshold and morphology of high reflectance optical coatings [6720-36]

G. Abromavicius, R. Buzelis, R. Drazdys, Institute of Physics (Lithuania); A. Melninkaitis, V. Sirutkaitis, Vilnius Univ. (Lithuania)

$6720 \mathrm{OZ}$ Short pulse laser damage measurements of pulse compression gratings for petawatt laser [6720-38] G. Razé, J. Néauport, G. Dupuy, Commissariat à l'Energie Atomique (France); M. Balas, VEDIORBIS (France); G. Mennerat, E. Lavastre, Commissariat à l'Energie Atomique (France)

\section{MATERIALS AND MEASUREMENTS}

672010 Final optics damage inspection (FODI) for the National Ignition Facility (Invited Paper) [6720-49] A. Conder, T. Alger, S. Azevedo, J. Chang, S. Glenn, L. Kegelmeyer, J. Liebman, M. Spaeth, P. Whitman, Lawrence Livermore National Lab. (USA)

672011 The relationship between laser fluence profile and the cumulative probability of damage curve [6720-51] J. W. Arenberg, Northrop Grumman Corp. (USA) 
672012 Comparative studies of laser-induced damage threshold measurements in highly reflecting mirrors [6720-45]

A. Melninkaitis, D. Mikšys, R. Grigonis, V. Sirutkaitis, Vilnius Univ. (Lithuania); M. Jupé, D. Ristau, Laser Zentrum Hannover e.V. (Germany)

672013 Comparison of Gaussian and top-hat beam profiles in LIDT testing [6720-43]

L. Jensen, M. Jupé, K. Starke, D. Ristau, Laser Zentrum Hannover e.V. (Germany); W. Riede, P. Allenspacher, German Aerospace Ctr. (Germany)

672014 Comparison between S/1 and R/1 tests and damage density vs. fluence $(\rho(\phi))$ results for unconditioned and sub-nanosecond laser-conditioned $\mathrm{KD}_{2} \mathbf{P O}_{4}$ crystals [6720-53]

J. J. Adams, J. A. Jarboe, M. D. Feit, R. P. Hackel, Lawrence Livermore National Lab. (USA)

672015 Laser damage investigation in $\mathrm{KTiOPO}_{4}(\mathrm{KTP})$ and $\mathrm{RbTiOPO}_{4}(\mathrm{RTP})$ crystals: threshold anisotropy and the influence of SHG [6720-54]

F. R. Wagner, A. Hildenbrand, J.-Y. Natoli, M. Commandre, Institut Fresnel, CNRS (France); F. Theodore, H. Albrecht, Cristal Laser S.A. (France)

672016 Influence of laser beam size and wavelength in the determination of LIDT and associated laser damage precursor densities in $\mathrm{KH}_{2} \mathbf{P O}_{4}$ [6720-56]

J. Y. Natoli, J. Capoulade, Institut Fresnel, CNRS (France); H. Piombini, B. Bertussi, Commissariat à l'Energie Atomique (France)

672017 Laser damage metrology in biaxial nonlinear crystals using different test beams (Best Poster Presentation) [6720-44]

A. Hildenbrand, F. R. Wagner, H. Akhouayri, J.-Y. Natoli, M. Commandre, Institut Fresnel, CNRS (France)

672018 Scaling in damage of optical materials by intensive laser radiation [6720-48]

E. K. Maldutis, Military Academy of Lithuania (Lithuania)

672019 Pump and probe damage testing for investigation of transient material modifications associated with laser damage in optical materials [6720-37]

R. A. Negres, M. D. Feit, P. DeMange, J. D. Bude, S. G. Demos, Lawrence Livermore National Lab. (USA)

$67201 \mathrm{~A}$ Measurement of initial absorption of fused silica at 193nm using laser induced deflection technique (LID) [6720-50]

D. Schönfeld, U. Klett, Heraeus Quarzglas GmbH and Co. KG (Germany); C. Mühlig, Institut für Photonische Technologien e.V. (Germany); S. Thomas, Heraeus Quarzglas GmbH and Co. KG (Germany)

6720 1B A novel photo-thermal setup for evaluation of absorption losses and thermal wavefront deformations in DUV optics [6720-72]

K. Mann, A. Bayer, T. Miege, U. Leinhos, B. Schäfer, Laser-Lab. Göttingen, e.V. (Germany)

6720 1C Spectrally resolved laser calorimetric absorptance measurements [6720-61]

L. Jensen, I. Balasa, K. Starke, D. Ristau, Laser Zentrum Hannover e.V. (Germany)

6720 1D Photothermal detuning: a sensitive technique for absorption measurement of optical thin films [6720-21] H. Hao, Institute of Optics and Electronics (China) and Graduate School of the Chinese Academy of Sciences (China); B. Li, Institute of Optics and Electronics (China); M. Liu, Y. Gong, Institute of Optics and Electronics (China) and Graduate School of the Chinese Academy of Sciences (China)

$67201 \mathrm{E} \quad$ Effect of instrumental response time in exponential-decay-based cavity ring-down techniques for high reflectivity measurement [6720-20]

Y. Gong, Institute of Optics and Electronics (China) and Graduate School of the Chinese Academy of Sciences (China); B. Li, Institute of Optics and Electronics (China) 
$67201 \mathrm{~F} \quad$ High-resolution 3D imaging of surface damage sites in fused silica with optical coherence tomography [6720-64]

G. Guss, I. Bass, R. Hackel, C. Mailhiot, S. G. Demos, Lawrence Livermore National Lab. (USA)

$67201 \mathrm{G}$ Selective cancellation of scattered light in optical substrates and coatings [6720-65]

C. Amra, C. Deumié, G. Georges, L. Arnaud, M. Zerrad, Institut Fresnel, CNRS (France); C. Grèzes-Besset, CILAS Marseille (France); F. Chazallet, SHAKTI SA (France)

$67201 \mathrm{H}$ Scattering-induced downstream beam modulation by plasma scalded mirrors [6720-67] J. R. Schmidt, M. J. Runkel, K. E. Martin, C. J. Stolz, Lawrence Livermore National Lab. (USA)

$67201 \mathrm{~J} \quad$ Effect of random clustering on surface damage density estimates [6720-55]

M. J. Matthews, M. D. Feit, Lawrence Livermore National Lab. (USA)

$67201 \mathrm{~K} \quad 248 \mathrm{~nm}$ high fluence irradiation of $\mathbf{C a F}_{2}$ crystals [6720-40]

A. Burkert, Institut für Photonische Technologien e.V. (Germany); D. Keutel, U. Natura, Schott Lithotec AG (Germany)

$67201 \mathrm{~L}$ Comparison of ns and sub-ns laser conditioning of KDP and DKDP crystals for high-power lasers [6720-42]

C. Maunier, CEA-CESTA (France); B. Bertussi, D. Damiani, CEA-Le Ripault (France); T. Donval, CEA-CESTA

(France); G. Duchateau, A. Dyan, CEA-Le Ripault (France); G. Gaborit, L. Lamaignère, CEA-CESTA (France);

X. Leborgne, CEA-Le Ripault (France); M. Loiseau, CEA-CESTA (France); H. Mathis, CEA-Le Ripault

(France); G. Raze, CEA-CESTA (France)

$67201 \mathrm{M}$ Optical damage threshold of silicon for ultrafast infrared pulses [6720-46]

B. M. Cowan, Tech-X Corp. (USA) and Stanford Linear Accelerator Ctr. (USA)

$67201 \mathrm{~N}$ Study of haze in artificially grown single crystal $\mathrm{CaF}_{2}[6720-71]$

M. Azumi, Nikon Corp. (Japan)

\section{MINI SYMPOSIUM: LIFETIME ISSUES FOR CW AND QUASI CW LASERS}

672010 Optical damage observed in the LHMEL II output coupler [6720-70]

J. J. Eric, Air Force Research Lab. (USA); J. O. Bagford, C. L. H. Devlin, R. J. Hull, D. B. Seibert, General Dynamics Information Technology, Inc. (USA)

6720 1R Effect of S and P polarization on single layer homogeneous model [6720-52]

U. Singh, A. Kapoor, Univ. of Delhi (India)

Abstracts

Participant List

Author Index 
Downloaded From: https://www.spiedigitallibrary.org/conference-proceedings-of-spie on 26 Apr 2023

Terms of Use: https://www.spiedigitallibrary.org/terms-of-use 


\section{Foreword}

This volume contains papers presented at the $39^{\text {th }}$ Annual Symposium on Optical Materials for High-Power Lasers that was held at the National Institute of Standards and Technology in Boulder, Colorado, 24-26 September 2007. The symposium was cosponsored by Lawrence Livermore National Laboratory (USA). Cooperating organizations were the Center for High Technology Materials at the University of New Mexico (USA), Pacific Northwest National Laboratory (USA), Laser Zentrum Hannover e.V. (Germany), the National Institute of Standards and Technology (USA), Electro-Magnetic Remote Sensing Defence Technology Centre (United Kingdom), and the College of Optics and Photonics, CREOL \& FPCE, University of Central Florida (USA). The symposium was attended by 149 scientists and engineers from Canada, China, France, Germany, Israel, Japan, Lithuania, the United Kingdom, and the United States. One-third of the attendees and half of the presentations were from abroad. A mini-symposium held on Wednesday afternoon addressed lifetime issues associated with $\mathrm{CW}$ and quasi $\mathrm{CW}$ lasers and highlighted our growing interest in this important area. Including the mini-symposium, 67 papers were presented in oral and poster sessions.

The meeting offered an opportunity to both renew old friendships and make new acquaintances. As usual, the National Institute of Standards and Technology in Boulder, Colorado, offered a relaxed setting conducive to promote exchanges between individuals working in closely related and complementary fields. NIST continues to be our selected venue for this meeting and we look forward to future opportunities to again come together here. The symposium is traditionally partitioned into the five technical sessions that address the following topics: thin films; surfaces, mirrors, and contamination; fundamental mechanisms; materials and measurements; and finally, a mini-symposium that, this year, focused on optics in a hostile environment. Dr. Gregory J. Exarhos of Pacific Northwest National Laboratory (USA), Dr. Arthur H. Guenther of the Center for High Technology Materials at the University of New Mexico (USA), Dr. Keith L. Lewis of Electro-Magnetic Remote Sensing Defence Technology Centre (UK), Dr. Detlev Ristau from the Laser Zentrum Hannover e.V. (Germany), Dr. M. J. Soileau, Vice-President of Research at the University of Central Florida (USA), and Mr. Christopher J. Stolz of the Lawrence Livermore National Laboratory (USA) cochaired the symposium.

The editors assume full responsibility for the summary article, which contains a highlighted overview of the symposium. Only manuscripts that were presented at the symposium appear in this volume and questions pertaining to these articles should be addressed directly to the authors. The interested reader is referred to the bibliography at the end of the summary article for general references to the literature of laser damage studies.

The 40th Annual Symposium of this SPIE-sponsored series will again be held in Boulder, Colorado, 22-24 September 2008. Suggestions from meeting attendees regarding prospective future technical topics to be addressed at this conference have been communicated to and reviewed by the organizing committee. Next year's program will likely offer a mini-symposium topic on optic lifetime issues associated with fused silica.

The principal topics to be considered in the 2008 technical program do not differ drastically from those covered in this volume. With the construction of multiple petawatt facilities around the world, we expect to hear more about damage mechanisms down to the femtosecond regime, damage effects from short wavelength irradiation including the $\mathrm{x}$-ray region, new optical materials design approaches, and transfer of underpinning fundamental science results to the 
commercial sector for development of innovative processing and cleaning applications. High brightness sources at shorter wavelengths continue to be of interest, and a corresponding shift in emphasis to damage problems associated with short-wavelength and repetitively pulsed irradiation of optical elements is envisioned in next year's program. Innovative fabrication approaches and more reliable test procedures are of continuing interest, particularly in the area of thin films. New materials and the impact of defects on the damage process will continue to be emphasized, as will further reports on conditioning effects and damage repair or mitigation.

As was initially established in 1992, several distinguished speakers will be invited to deliver presentations of a tutorial or review nature; in addition, late-breaking developments of interest to the laser damage community will be covered in other contributions.

The aim of this annual symposium series is to encourage exchange of information regarding optical materials for high-power/high-energy lasers. The editors welcome comments and criticism relevant to this purpose from all interested readers.

Gregory J. Exarhos, Pacific Northwest National Laboratory (USA)

Arthur H. Guenther, Center for High Technology Materials at the University of New Mexico (USA)

Keith L. Lewis, Electro-Magnetic Remote Sensing Defence Technology Centre (United Kingdom)

Detlev Ristau, Laser Zentrum Hannover e.V. (Germany)

M. J. Soileau, University of Central Florida (USA)

Christopher J. Stolz, Lawrence Livermore National Laboratory (USA) 


\section{International Program Committee}

The cochairs of this series of symposia rely heavily on an International Program Committee to ensure their awareness of significant research in the broad field of laser-induced damage throughout the world. Its members are also frequently the source of suggestions for invited speakers and mini-symposium topics and leaders. The committee performs a vital service as an outreach for the conference on a global scale. Individuals with suggestions for the meeting are requested to contact any committee member (next page) who is either an acquaintance or in close proximity. The committee is ably led by Keith Lewis, International Program Committee Chair and Detlev Ristau, International Program Committee Cochair.

Gregory J. Exarhos (greg.exarhos@pnl.gov)

Arthur H. Guenther (agun@chtm.unm.edu)

Keith L. Lewis (kllewis@qinetiq.com)

Detlev Ristau (dr@lzh.de)

M. J. Soileau (mj@mail.ucf.edu)

Christopher J. Stolz (stolz1@llnl.gov) 


\section{International Program Committee}

Keith L. Lewis, Chair

Electromagnetic Remote Sensing Defence

Technology Centre

United Kingdom

Detlev Ristau, Cochair

Laser Zentum Hannover eV

Laser Components Dept

Hollerithallee 8

Hannover, 30419 Germany

Claude Amra

Institut Fresnel ENSPM

CNRS EGIM

Domaine de Saint Jerôme

Marseille Cedex 2013397 France

James E. Andrew

Atomic Weapons Establishment Plc

Bldg C15-1

Aldermaston

Reading Berks RG7 4PR United Kingdom

Hervé Bercagol

CEA-CESTA

BP2

15 Ave des Sablieres

Le Barp, 33114 France

Michael D. Feit

Lawrence Livermore National Lab, L-491

7000 East Avenue

Livermore, CA 94550-0808 USA

Jerome B. Franck

U.S. Army Night Vision \& Electronic Sensors

Directorate

10221 Burbeck Rd

Fort Belvoir, VA 22060-5806 USA

Leonid Glebov

CREOL/Univ. of Central Florida

School of Optics

4000 Central Florida Blvd.

Orlando, FL 32816-8005 USA
Vitaly E. Gruzdev

University of Missouri-Columbia

E2403B Thomas \& Nell Lafferre Hall

Columbia, MO 65211 USA

Klaus Mann

Laser Laboratorium Göttingen e.V.

Hans-Adolf-Krebs-Weg

37077 Göttingen Germany

Masataka M. Murahara

Tokai University

Electrical Engineering Department

1117 Kitakaname

Hiratsuka-shi Kanagawa 259-1292 Japan

Semyon Papernov

University of Rochester

Laboratory of Laser Energetics

250 East River Rd.

Rochester, NY 14623-1299 USA

Amy L. Rigatti

University of Rochester

Laboratory for Laser Energetics

250 East River Rd.

Rochester, NY 14632-1299 USA

Alan Stewart

The Boeing Co.

MC WB-58/L\&EOS

6633 Canoga Ave

Canoga Park, CA 91309-7922 USA

Kunio Yoshida

Osaka Institute of Technology

5-16-1, Ohmiya, Asahi-ku

Osaka 535-8585 Japan 


\title{
Symposium Welcome
}

\author{
On the Occasion of the Thirty-Ninth Boulder Damage Symposium
}

\section{Christopher J. Stolz}

Lawrence Livermore National Laboratory (USA)

On behalf of my fellow cochairs, Greg Exarhos, Art Guenther, Keith Lewis, Detlev Ristau, and M. J. Soileau, I extend a warm welcome to all participants to the 39th Annual Symposium on Optical Materials for High Power Lasers. The BDS conference has been designed to maximize interactions between researchers through the use of non-parallel sessions, question and answer periods at the end of oral talks, and poster sessions for more direct dialog between colleagues. A mixer the evening before the conference and a wine and cheese party on Tuesday evening also create opportunities to share research and build friendships with a wide range of international participants. Finally, Alpine Research Optics graciously hosts an open house on Monday evening creating an additional opportunity to network with fellow colleagues.

In 1969, Dr. Art Guenther and Dr. Alex Glass started this annual symposium on laser-induced damage in optical materials and Art has tirelessly cochaired this meeting since its inception. Unfortunately, we lost Art to cancer earlier this year. His absence will be felt by all since his contributions to the field have been so significant. This conference has been one of Art's favorite passions so he has been laying the groundwork for some time to continue his legacy. In 1990 SPIE began publishing the BDS proceedings and in 2002 SPIE also began handling the administrative functions of the conference. An International Program Committee was organized in 1997 to recommend invited speakers, mini-symposium topics, and to extend our reach into the international laser damage community. CDs were created of the earlier proceedings to make prior out-of-print work available to the damage community. Finally over the last five years, Art has moved to an advisory role, whereas the cochairs have taken more active roles in planning and implementation of the conference. Art's main lasting contribution to this conference is his high standards. The best way we can honor Art's legacy is by contributing high quality original work to this conference.

The growth of this conference is attributed to a number of forces. Early in our history, domestic military applications fed much of the initial growth. Reductions in defense spending in the late 1980s led to fewer papers as illustrated in Figure 1. Over the last two decades growth has been clearly achieved by foreign contributions, primarily from Europe and Asia, with laser fusion programs also acting as a catalyst. 


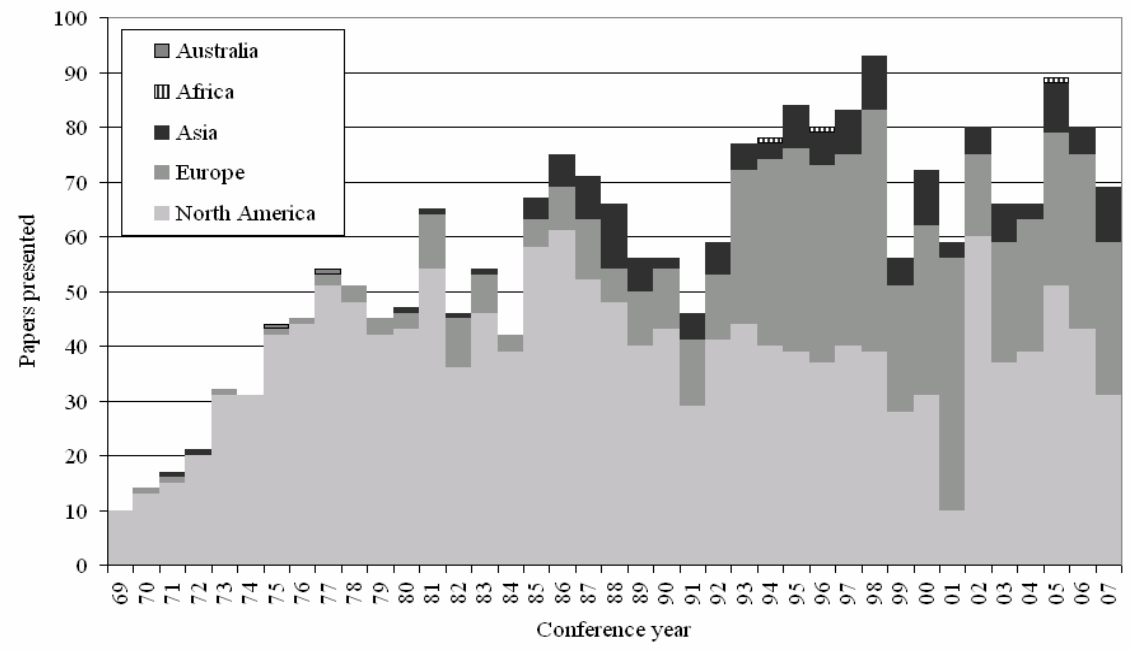

Fig. 1 Historical account of the continent of origin of primary authors contributing to the Boulder Damage Symposium.

The city of Boulder provides some spectacular scenery, excellent hiking and other outdoor activities, and great restaurants. I hope this setting provides a great opportunity to relax with old friends and perhaps establish new research opportunities. On behalf of my cochairs and the International Program Committee, I wish you a productive and enjoyable stay in Boulder and look forward to seeing you next year. 


\title{
Summary of Meeting
}

\author{
Laser-Induced Damage in Optical Materials \\ $39^{\text {th }}$ Annual Symposium \\ 24-26 September 2007 \\ Christopher J. Stolz \\ Lawrence Livermore National Laboratory \\ PO Box 808, L-491 \\ Livermore, CA 94551 USA
}

\begin{abstract}
These proceedings contain the papers presented as oral and poster presentations at the 39th Annual Symposium on Optical Materials for High-Power Lasers. The conference was held at the National Institute of Standards and Technology facility in Boulder Colorado, 24-26 September 2007. The symposium was divided into the traditional sessions devoted to the following topics: thin films; surfaces, mirrors and contamination; fundamental mechanisms; materials and measurements; and finally, a mini-symposium on lifetime issues for CW and quasi CW lasers. The conference started with two very touching tributes from Alex Glass and M.J. Soileau, in remembrance of the life of Dr. Art Guenther, the co-founder for this conference who has cochaired this conference from its inception. Doc Art with be truly missed, although his contributions to this conference will be longstanding. Dr. Gregory J. Exarhos of Pacific Northwest National Laboratory (USA), Dr. Keith L. Lewis of Electro-Magnetic Remote Sensing Defence Technology Centre (UK), Dr. Detlev Ristau of the Laser Zentrum Hannover e.V. (Germany), Dr. M. J. Soileau, of the University of Central Florida (USA), and Mr. Christopher J. Stolz of the Lawrence Livermore National Laboratory (USA), cochaired the symposium.

All told, 67 papers were presented, including oral and poster presentations plus a minisymposium. No parallel sessions were held, allowing the opportunity to discuss common research interests with all the presenters. With 149 participants attending, the meeting offered an opportunity to make many new acquaintances. Although held annually in the US, this is a truly international conference with 33 percent of the attendees and 55 percent of the presentations coming from abroad. As usual, the National Institute of Standards and Technology in Boulder, Colorado, offered a setting conductive to interchanges between individuals working in closely related and complementary fields. We look forward to future opportunities to again come together there.

The 40 ${ }^{\text {th }}$ Annual Symposium of this series will be held in Boulder, Colorado, 22-24 September 2008. A concerted effort will be made to ensure a close liaison between the high-peak-power and high-average-power communities, as well as to include damage issues related to various research efforts and commercial laser applications. A mini-symposium related to the subject of fused silica optics is anticipated. Plenary talks are also anticipated summarizing 40 years of contributions in the four major topical areas. Additionally a CD or DVD is anticipated being released which will include the papers from $2004-2008$ proceedings. Electronic copies of the prior years are also available on CD as listed in the references at the end of this paper.
\end{abstract}


The principal topics to be considered as contributed papers in 2008 do not differ drastically from those enumerated above. We expect to hear more about the impacts of contamination on the laser resistance of optical components and the impacts of defects since both of these topics continue to generate significant interest. High-energy laser windows and crystals continue to place limitations on laser systems, so remain an active area of research and spirited debate. Refinement of the mitigation strategy consisting of damage initiation followed by arresting damage growth through post-processing techniques while not creating downstream damage is also expected to be a continued focus as a large number of laser-resistant UV optics are manufactured for large-aperture fusion lasers. Short pulse laser optics and damage phenomena remain an active area of research. We also expect to hear more about new measurement techniques to improve our understanding of the different damage mechanisms or to improve the manufacturing of optical materials and thin films for optical components of greater laser damage resistance.

As was initially established in 1992, several distinguished invited speakers will make presentations of a tutorial or review nature, in addition, other contributors will cover late-breaking developments of interest to the attendees.

The purpose of this series of symposia is to exchange information about optical materials for high-power/high-energy lasers. The editors welcome comments and criticism from all interested readers relevant to this purpose.

Key words: laser damage, laser interaction, optical components, optical fabrication, optical materials and properties, thin film coatings, contamination.

\section{Introduction}

The 39th Annual Symposium on Optical Materials for High-Power Lasers (a.k.a. the Boulder Damage Symposium, because of its Boulder, Colorado, venue) was held 24-26 September 2007. This symposium continues to be the principal U.S. and international forum for the exchange of information relative to the interaction of intense laser light with optical media and components. Historically, the meeting has been divided into four broad categories: thin films; fundamental mechanisms; materials and measurements; and surfaces, mirrors, and contamination as illustrated in Figure 1.

\section{Thin Films}

Because of the tremendous range of applications of optical multilayers for modifying the optical performance of elements (e.g., reflectivity, wavelength sensitivities, polarization, or simply protection, etc.), this receives attention. Besides damage thresholds or sensitivity, topics include advanced thin deposition technology, film structure, film design, film response to environmental attack and aging, and numerous reports on important film properties such as adhesion, thermal conductivity, absorption, stability, defect identification, aging - drift and moisture infusion, and conditioning processes to improve performance. 


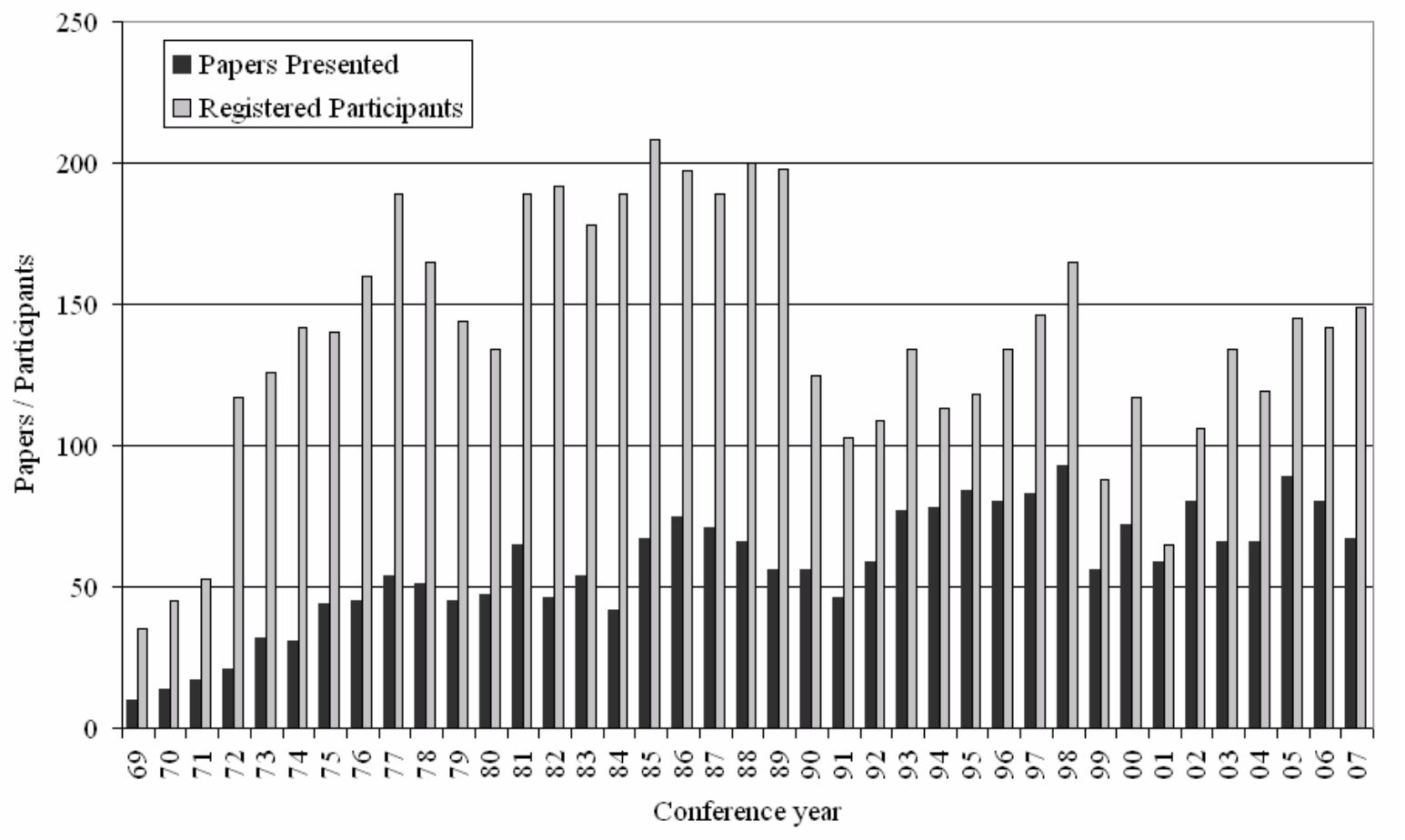

Topical emphasis of conference by year

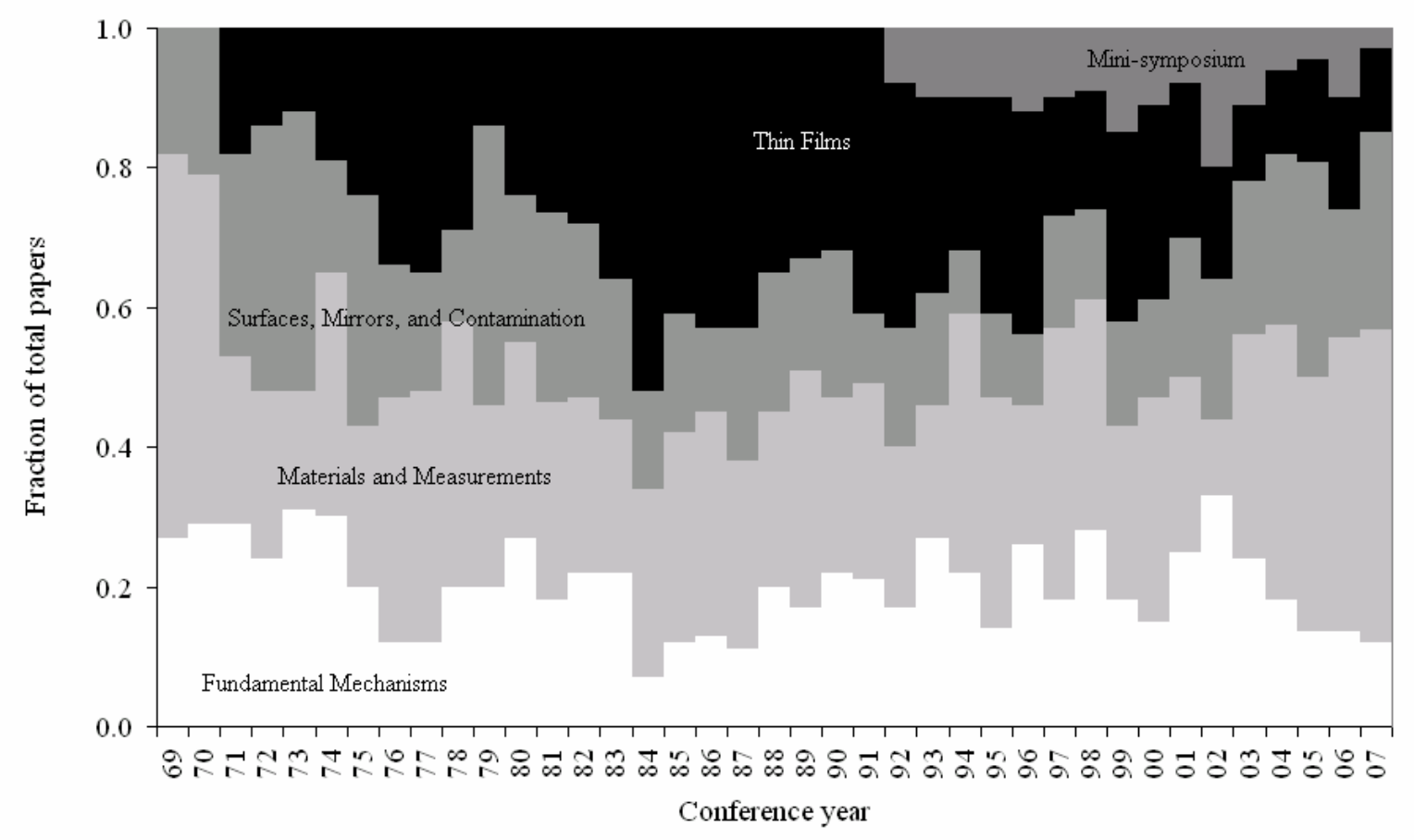

Fig. 1 Historical statistics of conference attendance and paper submission (top) and distribution of submissions by topical area (bottom). 
Dense thin film processes offer the benefit of environmental stability so much of the research in the field of thin films is proceeding in this direction. Laser interaction studies are uncovering areas were dense films offer advantages over traditional e-beam coatings. An example from the invited talk is the preconditioning of bare surfaces to increase the laser resistance of dense ion beam sputtered antireflection coatings.

Coating defects continue to be an area of active interest in both process optimization to minimize defect formation as well as mitigation techniques such as laser conditioning. This year we saw continued increase of interest in short pulse and DUV coatings.

\section{Fundamental Mechanisms}

This area deals with the interaction of light with matter - where real system experience is presented. Topics include nonlinear behavior, self-focusing, thermal modeling, and experimental data reduction protocols (e.g. effects of pulse width, repetition rate or duty cycle, spot size, wavelength, temperature, ionizing radiation, and other environmental effects), as well as all types of experimental or material variable scaling relationships that not only afford insight into the fundamentals of the interaction process, but allow extrapolations for engineering and costbenefit evaluations. In many areas, these insights are based on real-world, systems-level tests, as opposed to a frequently pristine laboratory environment.

Due to the interest in ultrashort phenomena, the invited speaker for the fundamental mechanisms session spoke on nanospallation induced by femtosecond pulses. Most of the damage research at long pulses (nanosecond and longer) focuses on sub-micron to micron-scale defects (coating nodules, subsurface cracks, absorbing polishing compounds) and thermomechanical damage. The need for laser resistant UV optics (KDP, DKDP, and fused silica) for laser fusion lasers continues to drive much of the discussion.

\section{Surfaces and Mirrors}

Here one will find presentations on surface preparation (including single-point diamond micromachining and ductile grinding), subsurface damage characterization, roughness and scattering, environmental degradation and aging, as well as substrate material properties, including cooling techniques, and, of course, damage measurements and the cleaning of surfaces. The crux of the contamination problem is fundamentally that damage experiments done in controlled clean laboratory settings do not necessarily yield the same results as laser operations in less pristine operating environments. A significant amount of work is needed in understanding what contamination is acceptable, what contamination is threatening to optic survivability, and how fluence-limiting or lifetime-limiting contamination can be eliminated or mitigated from operating laser systems.

The invited paper gave a tremendous overview of mirror technologies needed for the James Webb Space Telescope. Although not exactly a laser damage talk, issues with losses, coating stability, and micro-meteorite damage were still extremely relevant.

\section{Materials and Measurements}

This section deals with laser damage to the bulk of transparent optical media - whether amorphous, polymeric, polycrystalline, or crystalline - and its preparation, as well as reports of material properties of import to their optical function and/or the damage process, e.g., linear and 
nonlinear refractive indices, absorption, thermal conductivity, stress-optic coefficients, moduli, and defects. Also included are new techniques for measuring these quantities, which present a continuing challenge as materials are improved in quality and diversity.

There is always interest in improved measurement systems or new instruments. There were also some very spirited discussion and interest in carbon nanotubes. Finally, microstructure replacements for antireflection coatings to yield extremely high damage thresholds captured a lot of attention.

\section{Mini-Symposium on Lifetime Issues for CW and Quasi CW Lasers}

This year the meeting was concluded with a mini-symposium dealing with the topic of optics lifetime for $\mathrm{CW}$ lasers. Of particular interest were the results of the impacts of space environments on a variety of optical samples. Typically during the mini-symposium, a paper will be presented that is marginally relevant to the main topic of the meeting, but is an excellent review of the state of a specific technology. This was especially true for the paper on ophthalmic optics which are exposed to extremely hostile environments, although at extremely low photon flux. The mini-symposium was organized this year by Alan Stewart from The Boeing Company (USA).

\section{Invited Papers}

As usual, the 2007 meeting was highlighted by several invited papers. They included:

1. "Nanospallation induced by a femtosecond pulse," S. I. Anisimov, N. I. Lobachevsky, State University of Nizhni Novgorod (Russia).

2. "James Webb Space Telescope: a large deployable cryogenic telescope in space?" P. A. Lightsey, Ball Aerospace \& Technologies Corp. (USA).

3. "A laser preconditioning process for improving the laser damage threshold, and the search for subtle laser damage from long-duration laser exposure for IBS thin films," A. D. Streater, Research Electro-Optics inc. (USA).

4. "Final optics damage inspection (FODI) for the National Ignition Facility," A. D. Conder, Lawrence Livermore National Laboratory (USA).

\section{Conference Awards}

Beginning with the meeting in 2000, the organizers instituted a best paper award in the oral and poster categories. The awards appropriately take the form of laser-induced art in an optical glass plaque. (see, e.g., paper by I. N. Trotski, Proc. SPIE 4679, 392-399 (2001) plus a remuneration).

There were several outstanding posters and oral papers, however, the following papers were selected:

Best Oral Paper:

"High laser damage threshold surface relief micro-structures for antireflection mirror applications,” D. S. Hobbs, B. D. MacLeod, TelAztec LLC (USA). 
Best Poster Paper:

"Laser damage metrology in biaxial nonlinear crystals using focused test beams," A. Hildenbrand, F. R. Wagner, H. Akhouayri, J.-Y.Natoli, and M. Commandré, Institut Fresnel, CNRS (France).

\section{In Conclusion}

The location in Boulder, Colorado during autumn at the venue of the National Institute of Standards and Technology and its outstanding facilities and support staff were appreciated by all. The 149 attendees were easily accommodated with ample opportunity to mingle and socialize.

The organizers of the Boulder Damage Symposium look for opportunities to join with other related groups for joint meetings in the future. For example, in 2002 we had a joint meeting with the $7^{\text {th }}$ International Workshop on Laser Beam and Optics Characterization, again with no parallel sessions.

We must also take note of the tireless assistance of SPIE who handle the administrative functions of the symposium. Their presence, experience, resources, and professionalism clearly were made manifest with on-line reservations, payment by credit cards, badges, preparation of the abstract book and pocket programs, and on-line document service, to which we may add the social functions - thanks to them, "A good time was had by all."

\section{Acknowledgments}

A number of volunteers help tirelessly with some of the administrate duties necessary to put on a conference of this magnitude. Joan Guenther in the past has handled the residual financial assets of Laser Damage Conference, Inc., because the accountant for our nonprofit corporation resides in New Mexico. Susie McGuire, Administrative Assistant to Greg Exarhos, assists with transcriptions of technical questions asked at the end of each talk. Susie also assisted SPIE staff at the conference with registration, setup, and general questions.

Of course, we are all indebted to Kent Rochford, Division Chief of the Optoelectronics Division, who was the prime contact at NIST, for his continued support and encouragement, and Wendy Ortega, also of NIST, who together made it possible to hold a seamless meeting. On behalf of all the organizers and attendees, we thank them for their tireless efforts.

\section{References}

\section{Books:}

A. J. Glass and A. H. Guenther, eds. Damage in Laser Glass, ASTM Spec. Tech. Pub. 469, ASTM, Philadelphia, PA (1969).

N. Bloembergen, Fundamentals of Damage in Laser Glass, National Materials Advisory Board Publ. NMAB-271, National Academy of Sciences (1970).

N. Bloembergen, High-Power Infrared Laser Windows, National Materials Advisory Board Publ. NMAB-356 (1971).

R. M. Wood, Laser-Induced Damage in Optical Materials, Adam Hilger, Bristol (UK) (1986).

M. J. Weber, ed., Handbook of Laser Science and Technology, Vol. III: Optical Materials, Part 1: Nonlinear Optical Properties/Radiation Damage, CRC, Boca Raton, FL (1986).

M. J. Weber, ed., Handbook of Laser Science and Technology, Vol. IV: Optical Materials, Part 2: Properties, CRC, Boca Raton, FL (1986). 
M. J. Weber, ed., Handbook of Laser Science and Technology, Vol. V: Optical Materials, Part 3: Applications, Coatings, and Fabrication, CRC, Boca Raton, FL (1987).

R. M. Wood, Ed., Selected Papers on Laser Damage in Optical Materials, SPIE Milestone Series Vol. MS24, Bellingham, WA (U.S.) (1990).

M. R. Kozlowski, Damage-Resistant Laser Coatings, in Thin Films for Optical Systems, F. Flory, ed., Marcel Dekker, New York, 521-549 (1995).

M. J. Weber, ed., Handbook of Laser Science and Technology, Suppl. 2, Optical Materials, CRC, Boca Raton, FL, (1995).

A. H. Guenther, ed., International Trends in Applied Optics, SPIE Press monograph, Bellingham, Washington, Chapters 1, 3, 8, 9, 10, \& 12 (2002).

M. J. Weber, ed., Handbook of Optical Materials, CRC, Boca Raton, FL (2002).

R. M. Wood, The Power and Energy-Handling Capability of Optical Material, Components, and Systems, (Tutoriual Texts in Optical Engineering Vol TT60 A. R. Weeks Series Editor SPIE Press Bellingham WA) (2003).

R. M. Wood, Laser Induced Damage of Optical Materials (Institute of Physics Publishing, Bistrol, UK) (2003).

C. J. Stolz and F. Y. Génin, Laser Resistant Coatings, in Optical Interference Coatings, N. Kaiser and H. Pulker, eds., Springer-Verlag, Berlin, 310-333 (2003).

\section{Proceedings:}

A. J. Glass and A. H. Guenther, eds., Damage in Laser Materials, Nat. Bur. Stand. (U.S.) Spec. Publ. 341 (1970).

A. J. Glass and A. H. Guenther, Eds., Damage in Laser Materials: 1971, Nat. Bur. Stand. (U.S.) Spec. Publ. 356 (1971).

A. J. Glass and A. H. Guenther, eds., Laser-Induced Damage in Optical Materials: 1972, Nat. Bur. Stand. (U.S.) Spec. Publ. 372 (1972).

A. J. Glass and A. H. Guenther, Eds., Laser-Induced Damage in Optical Materials: 1973, Nat. Bur. Stand. (U.S.) Spec. Publ. 387 (1973).

A. J. Glass and A. H. Guenther, eds., Laser-Induced Damage in Optical Materials: 1974, Nat. Bur. Stand. (U.S.) Spec. Publ. 414 (1974).

A. J. Glass and A. H. Guenther, eds., Laser-Induced Damage in Optical Materials: 1975, Nat. Bur. Stand. (U.S.) Spec. Publ. 435 (1975).

A. J. Glass and A. H. Guenther, eds., Laser-Induced Damage in Optical Materials: 1976, Nat. Bur. Stand. (U.S.) Spec. Publ. 462 (1976).

A. J. Glass and A. H. Guenther, eds., Laser-Induced Damage in Optical Materials: 1977, Nat. Bur. Stand. (U.S.) Spec. Publ. 509 (1977).

A. J. Glass and A. H. Guenther, eds., Laser-Induced Damage in Optical Materials: 1978, Nat. Bur. Stand. (U.S.) Spec. Publ. 541 (1978).

H. E. Bennett, A. J. Glass, A. H. Guenther, and B. E. Newnam, eds., Laser-Induced Damage in Optical Materials: 1979, Nat. Bur. Stand. (U.S.) Spec. Publ. 568 (1979).

H. E. Bennett, A. J. Glass, A. H. Guenther, and B. E. Newnam, eds., Laser-Induced Damage in Optical Materials: 1980, Nat. Bur. Stand. (U.S.) Spec. Publ. 620 (1981).

H. E. Bennett, A. J. Glass, A. H. Guenther, and B. E. Newnam, eds., Laser-Induced Damage in Optical Materials: 1981, Nat. Bur. Stand. (U.S.) Spec. Publ. 638 (1983).

H. E. Bennett, A. H. Guenther, D. Milam, and B. E. Newnam, eds., Laser-Induced Damage in Optical Materials: 1982, Nat. Bur. Stand. (U.S.) Spec. Publ. 669 (1984).

H. E. Bennett, A. H. Guenther, D. Milam, and B. E. Newnam, eds., Laser-Induced Damage in Optical Materials: 1983, Nat. Bur. Stand. (U.S.) Spec. Publ. 688 (1985). 
H. E. Bennett, A. H. Guenther, D. Milam, and B. E. Newnam, eds., Laser-Induced Damage in Optical Materials: 1984, Nat. Bur. Stand. (U.S.) Spec. Publ. 727 (1986).

H. E. Bennett, A. H. Guenther, D. Milam, and B. E. Newnam, eds., Laser-Induced Damage in Optical Materials: 1985, Nat. Bur. Stand. (U.S.) Spec. Publ. 746 (1987).

H. E. Bennett, A. H. Guenther, D. Milam, and B. E. Newnam, eds., Laser-Induced Damage in Optical Materials: 1986, Nat. Bur. Stand. (U.S.) Spec. Publ. 752 (1987).

H. E. Bennett, A. H. Guenther, D. Milam, B. E. Newnam, and M. J. Soileau, eds., Laser-Induced Damage in Optical Materials: 1987, Nat. Bur. Stand. (U.S.) Spec. Publ. 756 (1988).

H. E. Bennett, A. H. Guenther, B. E. Newnam, and M. J. Soileau, eds., Laser-Induced Damage in Optical Materials: 1988, Nat. Bur. Stand. (U.S.) Spec. Publ. 775 (1989).

H. E. Bennett, L. L. Case, A. H. Guenther, B. E. Newnam, and M. J. Soileau, eds., Laser-Induced Damage in Optical Materials: 1989, NIST (U.S.) Spec. Publ. 801, ASTM STP 1117 and Proc. SPIE 1438 (1989).

H. E. Bennett, L. L. Case, A. H. Guenther, B. E. Newnam, and M. J. Soileau, eds., Laser-Induced Damage in Optical Materials: 1990, ASTM STP 1141 and Proc. SPIE 1441 (1991).

H. E. Bennett, L. L. Case, A. H. Guenther, B. E. Newnam, and M. J. Soileau, eds., Laser-Induced Damage in Optical Materials: 1991, Proc. SPIE 1624 (1992).

H. E. Bennett, L. L. Case, A. H. Guenther, B. E. Newnam, and M. J. Soileau, eds., Laser-Induced Damage in Optical Materials: 1992, Proc. SPIE 1848 (1993).

H. E. Bennett, L. L. Case, A. H. Guenther, B. E. Newnam, and M. J. Soileau, eds., Laser-Induced Damage in Optical Materials: 1993, Proc. SPIE 2114 (1994).

H. E. Bennett, A. H. Guenther, M. R. Kozlowski, B. E. Newnam, and M. J. Soileau, eds., LaserInduced Damage in Optical Materials: 1994, Proc. SPIE 2428 (1995).

H. E. Bennett, A. H. Guenther, M. R. Kozlowski, B. E. Newnam, and M. J. Soileau, eds., LaserInduced Damage in Optical Materials: 1995, Proc. SPIE 2714 (1996).

H. E. Bennett, A. H. Guenther, M. R. Kozlowski, B. E. Newnam, and M. J. Soileau, eds., LaserInduced Damage in Optical Materials: 1996, Proc. SPIE 2966 (1997).

G. J. Exarhos, A. H. Guenther, M. R. Kozlowski, and M. J. Soileau, eds., Laser-Induced Damage in Optical Materials: 1997, Proc. SPIE 3244 (1998).

G. J. Exarhos, A. H. Guenther, M. R. Kozlowski, K. Lewis, and M. J. Soileau, eds., Laser-Induced Damage in Optical Materials: 1998, Proc. SPIE 3578 (1999).

G. J. Exarhos, A. H. Guenther, M. R. Kozlowski, K. Lewis, and M. J. Soileau, eds., Laser-Induced Damage in Optical Materials: 1999, Proc. SPIE 3902 (2000).

G. J. Exarhos, A. H. Guenther, M. R. Kozlowski, K. Lewis, and M. J. Soileau, eds., Laser-Induced Damage in Optical Materials: 2000, Proc. SPIE 4347 (2001).

G. J. Exarhos, A. H. Guenther, K. Lewis, M. J. Soileau, and C. J. Stolz eds., Laser-Induced Damage in Optical Materials: 2001, Proc. SPIE 4679 (2002).

G. J. Exarhos, A. H. Guenther, K. Lewis, N. Kaiser, M. J. Soileau, and C. J. Stolz eds., LaserInduced Damage in Optical Materials: 2002, Proc. SPIE 4932 (2003).

G. J. Exarhos, A. H. Guenther, K. Lewis, N. Kaiser, M. J. Soileau, and C. J. Stolz eds., LaserInduced Damage in Optical Materials: 2003, Proc. SPIE 5273 (2004).

G. J. Exarhos, A. H. Guenther, K. Lewis, N. Kaiser, M. J. Soileau, and C. J. Stolz eds., LaserInduced Damage in Optical Materials: 2004, Proc. SPIE 5647 (2005).

G. J. Exarhos, A. H. Guenther, K. Lewis, D. Ristau, M. J. Soileau, and C. J. Stolz eds., LaserInduced Damage in Optical Materials: 2005, Proc. SPIE 5991 (2006).

G. J. Exarhos, A. H. Guenther, K. Lewis, D. Ristau, M. J. Soileau, and C. J. Stolz eds., LaserInduced Damage in Optical Materials: 2006, Proc. SPIE 6403 (2007). 


\section{Compact Discs:}

A. H. Guenther, ed., Laser-Induced Damage in Optical Materials: Collected papers 1969-1998 (a three CD-ROM set available from SPIE, P.O. Box 10, Bellingham, WA 98227-0010) (1999).

A. H. Guenther, ed., Laser-Induced Damage in Optical Materials: Collected papers 1999-2003 (CD-ROM available from SPIE, P.O. Box 10, Bellingham, WA 98227-0010) (2004).

\section{Journal articles:}

A. J. Glass and A. H. Guenther, eds., Laser-Induced Damage in Optical Materials: A conference Report, Appl. Opt. 13 (1): 74-88 (1974).

A. J. Glass and A. H. Guenther, eds., Laser-Induced Damage in Optical Materials: $6^{\text {th }}$ ASTM Symposium, Appl. Opt. 14 (3): 698-715 (1975).

A. J. Glass and A. H. Guenther, eds., Laser-Induced Damage in Optical Materials: $7^{\text {th }}$ ASTM Symposium, Appl. Opt. 15 (6): 1510-1529 (1976).

A. J. Glass and A. H. Guenther, eds., Laser-Induced Damage in Optical Materials:87th ASTM Symposium, Appl. Opt. 16 (5): 1214-1231 (1977).

A. J. Glass and A. H. Guenther, eds., Laser-Induced Damage in Optical Materials: 9th ASTM Symposium, Appl. Opt. 17 (6): 2386-2411 (1978).

A. J. Glass and A. H. Guenther, eds., Laser-Induced Damage in Optical Materials: $10^{\text {th }}$ ASTM Symposium, Appl. Opt. 18 (13): 2212-2229 (1979).

H. E. Bennett, A. J. Glass, A. H. Guenther, and B. E. Newnam, eds., Laser-Induced Damage in Optical Materials: 11 th ASTM Symposium, Appl. Opt. 19 (14): 2375-2397 (1980).

H. E. Bennett, A. J. Glass, A. H. Guenther, and B. E. Newnam, eds., Laser-Induced Damage in Optical Materials: 12th ASTM Symposium, Appl. Opt. 20 (17): 3003-3019 (1981).

H. E. Bennett, A. H. Guenther, D. Milam, and B. E. Newnam, eds., Laser-Induced Damage in Optical Materials: 13 th ASTM Symposium, Appl. Opt. 22 (20): 3276-3296 (1983).

H. E. Bennett, A. H. Guenther, D. Milam, and B. E. Newnam, eds., Laser-Induced Damage in Optical Materials: 14th ASTM Symposium, Appl. Opt. 23 (21): 3782-3795 (1984).

H. E. Bennett, A. H. Guenther, D. Milam, and B. E. Newnam, eds., Laser-Induced Damage in Optical Materials: 15 th ASTM Symposium, Appl. Opt. 25 (2): 258-275 (1986).

H. E. Bennett, A. H. Guenther, D. Milam, and B. E. Newnam, eds., Laser-Induced Damage in Optical Materials: 16 $6^{\text {th }}$ ASTM Symposium, Appl. Opt. 26 (5): 813-827 (1987).

A. H. Guenther, "Optics damage constrains laser design and performance," Laser Focus World, 29, 83-87, 1992.

A. H. Guenther, "Previewing the Boulder Damage Symposium," Lasers and Optronics 12, 2526,1993.

A. H. Guenther, "Laser-Induced Damage in Optical Materials at the October 6-8, 1997 Symposium on Optical Materials for High-Power Lasers (Boulder Damage Symposium), Boulder, Colorado" J. Laser Appl. 9, 261-266,1997. 
Downloaded From: https://www.spiedigitallibrary.org/conference-proceedings-of-spie on 26 Apr 2023

Terms of Use: https://www.spiedigitallibrary.org/terms-of-use 


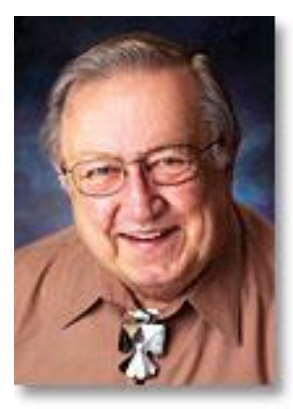

\title{
A Tribute to Dr. Arthur Guenther (1931-2007)
}

\author{
Alexander J. Glass \\ Executive Vice-President for Instrumentation \\ KineMed, Inc.
}

With the death of Dr. Arthur Guenther on April 23, 2007, the world of optics has lost a powerful and effective advocate. His contributions ranged over a wide variety of activities, including science, education, technology policy, economic development, and international cooperation. The loss was even greater for all of us who interacted with Art on a personal level, for whom his passing deprived us of a friend, a mentor, a critic, and an inspiration.

Art Guenther was born in Hoboken, New Jersey, on April 20, 1931. He attended Rutgers University where he received a B.S. in Chemistry, and went on to receive his Ph.D. in Chemistry and Physics from Penn State University in 1957. While at Penn State, he worked in David Rank's spectroscopy laboratory, an experience that influenced his decision to pursue a career in optics.

After his graduate studies, Art embarked on his long career with the U.S. Air Force, and spent 31 years at the Kirtland Air Force Base, much of it as Chief Scientist of the Air Force Weapons Laboratory (now part of the Air Force Research Laboratory). Like most of his contemporaries, Art was trained in pre-laser optics and spectroscopy. He entered into his professional career at a time of great excitement, with the first demonstration of the laser in 1960, and the subsequent discovery of Q-switching two years later, making it possible to concentrate light on materials at a very high intensity, albeit for a brief interval. Throughout his career, Art retained a passionate interest in the interaction of intense light and matter, and co-founded the Symposium on Optical Materials for High Power Lasers (the Boulder Damage Symposium). At this, the 39th annual meeting of the Symposium, it is fitting that we take some time to recognize Art's contributions to science, and to honor his many achievements.

I had the privilege of working closely with Art for the first 10 years of the Boulder Damage Symposium, and we remained friends and occasional collaborators throughout his life. After his death, I contacted a number of his friends, former students, and professional colleagues, and asked them to collaborate in creating a collection of articles 
in tribute to Art. The response was uniformly positive, and copies of this tribute volume will be distributed to everyone attending the Symposium ${ }^{1}$. This is not just a collection of technical articles, although many of the contributions are technical in nature. The purpose of this volume has several dimensions; it is intended to recognize the breadth and diversity of Art's contributions, to provide personal insights into his productive career, to give his friends and colleagues an opportunity to express their appreciation, and to provide a portrait of the man as well as his accomplishments.

I want to express my personal thanks to the SPIE for generous support of this project. Particular thanks go to Eugene Arthurs, Executive Director of SPIE, for making the project possible, to Merry Schnell, who provided expert and professional editing for the volume, and to Bobbie Lively, for administrative support. I also want to thank the contributors to the volume, for taking time from their busy lives and careers to create their personal remembrances of Art, and to search through their personal archives for appropriate photographs. I am especially grateful to M.J. Soileau, who provided me with excellent suggestions for added contributors, and good advice relating to the project overall.

In this brief memoir, it is not possible to enumerate all of Art's achievements and the dozens of awards that he received. This is an audience made up of specialists in optics and optical materials, so you are all quite familiar with Art's contributions to those subjects. Art was a fellow of SPIE, the IEEE, and the Optical Society of America. He and I co-founded the Boulder Damage Symposium in 1967, but that history has been well-covered in previous meetings, and in the memorial volume. However, many in this audience are not as familiar with his contributions to pulsed power, national security, international cooperation, technical education, economic development and science policy. A quick review of his achievements in these areas will give you a picture of the breadth and depth of his many interests.

Art's interest in high voltage technology (pulsed power) stemmed from his work on simulation of the environmental effects of nuclear weapons, for which he received the Harry Diamond Award of the IEEE, in 1971. Art and his colleagues at Kirtland pioneered the development of laser-triggered spark gaps, a subject that merged two of Art's lifelong interests. In conjunction with Professor Kris Kristiansen at Texas Tech University, Art founded the IEEE International Conference on Pulsed Power in 1976. He received the IEEE Peter Haas Pulsed Power Award at this conference in 1989. In recognition of his contributions, he was honored at an extended plenary session of the pulsed power conference in 2007, and the annual "Outstanding Pulsed Power Student Award" was renamed as "the Arthur H. Guenther Pulsed Power Student Award."

Art's contributions to national security were many - he served as Chief Scientist of the Air Force Weapons Laboratory for many years. In addition to his direct contributions, as detailed above, his leadership and mentoring helped develop his students and colleagues, and expanded their contributions as well. In 1985, President Ronald Reagan awarded Art the Presidential Distinguished Senior Executive Service Award, which Art considered as one of his highest achievements.

We have been privileged to have international participation in the Boulder Damage Symposium almost from the inception. Throughout his life, Art championed the cause of international collaboration in science. He served on the U.S. Advisory Committee for 
the International Commission on Optics (ICO) from 1996 to 1999, and as President of the ICO from 1999 to 2002. Under Art's leadership, the tri-annual international meeting of the ICO was held in San Francisco in 1999, the first time that it had come to the U.S. in 27 years. Art was also a frequent participant and strong supporter of the Russian equivalent of the Boulder Damage Symposium, the conference on "Non-Resonant Laser-Matter Interaction (NLMI)," which is held every two years in St. Petersburg. His interest in fostering scientific collaboration between the U.S. and Russia was recognized formally in 1992, when Art was named a fellow of the Urals Branch of the Russian Academy of Sciences.

In the 1970s, the environmental movement coined the phrase, "Think Globally, Act Locally." Art Guenther personified that philosophy. While active on the global stage, he continued to create and develop programs of local interest and benefit. He served as science advisor to three governors of his home state of New Mexico. He advised New Mexico's two senators and congressional representative. At Art's death, Senator Jeff Bingaman entered an extensive tribute to him in the Congressional Record, which is reprinted in the memorial volume. As is described by Eugene Arthurs' article in that volume, Art was active in SPIE, serving on the Board of Directors from 1996 to 2001. This year, SPIE and the Optical Society of America renamed their joint Congressional Fellowship as the "Arthur H. Guenther Congressional Fellowship Program."

Art was a passionate believer in the value of optics and photonics as an engine of economic development, both internationally and locally. As Chair of the State Science and Technology Committee, he helped create a plan for economic development in New Mexico that called for the formation of five centers of excellence, including what is now the Center for High Temperature Materials (CHTM) at the University of New Mexico. As will be described by Professor Soileau, Art helped create the Center for Research in Electro-Optics and Lasers (CREOL) at the University of Central Florida, and was named a lifetime member of their Industrial Affiliates. Art was instrumental in forming the Alliance for Photonic Technology in New Mexico, consisting of the Air Force Research Laboratory, Los Alamos National Laboratory, Sandia National Laboratory and CHTM. The New Mexico Optical Industries Association recognized Art's local contributions to the advancement of the optics industry by posthumously awarding him their Lifetime Service Award.

Art recognized that the advancement of the field of optics depended entirely on a foundation of technical education, comprising all levels from secondary school to post doctoral studies. He worked closely with Dan Hull and Leno Pedrotti at the Center for Occupational R\&D at Texas State Technical Institute to establish one of the first programs for training laser technicians, and served as Chair of the Center's Board of Directors. He was active in expanding education and training in optics internationally, both through the ICO and the International Conference on Education and Training in Optics and Photonics (ETOP). A tribute to Art was given at the 2007 ETOP meetings in Ottawa in June 2007 and in Cape Coast, Ghana in November. At the secondary school level, he helped to create a special Photonics Academy at the West Mesa High School in Albuquerque, which was recently named the "Arthur Henry Guenther Photonics Academy" in his honor. 
How was one man capable of achieving all this in a single lifetime? The answer to that question lies in large part in Art's personal style of leadership. First of all, he was never just a participant in an activity, but quickly moved to a leadership position. Furthermore, he was never satisfied with just producing a report or studying a situation - he invariably wanted to translate talk into action and recommendations into programs. He was well aware of the limitations of acting alone, and was tremendously effective in enlisting the support and participation of others. It was very hard to say no to Art, but he always was ready to explain why you should say yes. He believed strongly that if he took a controversial position (as he occasionally did) that it was incumbent on him to explain the reasoning behind his decision, to help bring others around to his point of view, or at least, make the issues clear if they wished to disagree. Furthermore, if the issue was technical, he wanted to understand the underlying science. The Boulder Damage Symposium arose from just such an issue: What limits were placed on the performance of high power lasers by the interaction of intense light with optical materials? Art was not satisfied in just finding ways to avoid laser damage; he realized the importance of understanding how damage came about, and how it scaled with pulse duration, rep rate, frequency and type of material. His insistence on establishing the scientific basis of optical damage made the symposium the leading forum in the world for this subject, and laid the basis for applying so-called damage mechanisms constructively, to laser machining and materials processing, now a $\$ 1.7$ billion industry world-wide.

It can be said of Art that he didn't just have interests, he had passions. His passions were infectious, and he drew others into his activities through his enthusiasm and dedication. For those who worked with him, he was an accomplished scientist, a natural leader, a mentor and above all, a friend. Never formal, he was always "Art" or "Doc" to those who knew him. Always approachable, he was never too busy to help someone in need. The tribute volume contains several testimonials to Art's readiness to help others, either on a professional or personal level.

Art drew great strength and support from his family. His wife Joan, and his daughters, Tracie and Wendy, took on the added burden of Art's long working hours and intensive travel schedule. They share in all the honors that he received. Pat Whited, who served as his administrative assistant and "right-hand man" for much of his career, contributed greatly to his success and productivity as well.

As President of the ICO, Art spoke often about this being "The Age of Light." He saw clearly the promise of optical science and technology, and how it could be a force for progress and prosperity. Our challenge is to fulfill his vision of international cooperation, global scientific education and technology-based economic development.

\footnotetext{
1 “A Tribute to Dr. Arthur H. Guenther”" SPIE (2007)
} 